Tomasz Rachwat

Uniwersytet Pedagogiczny, Kraków, Polska

\title{
Rola przedsiębiorstw przemysłowych w rozwoju gospodarki opartej na wiedzy
}

\section{The Role of Industrial Enterprises in the Development of the Knowledge-Based Economy}

\begin{abstract}
Streszczenie: W artykule zaproponowano ujęcie modelowe współczesnych, związanych z gospodarką opartą na wiedzy (GOW), uwarunkowań rozwoju przedsiębiorstw przemysłowych oraz podstawowych implikacji ich funkcjonowania dla kształtowania się tego typu gospodarki, w odniesieniu do przestrzeni geograficznej. W efekcie w rozważaniach zmierza się do określenia wpływu uwarunkowań społeczno-ekonomicznych, kulturowych i przyrodniczych związanych z GOW na funkcjonowanie przedsiębiorstw przemysłowych, a z drugiej strony do określenia w jakim zakresie te przedsiębiorstwa wpływają na rozwój poszczególnych elementów przestrzeni geograficznej, stanowiących zarazem komponent GOW. Propozycję ujęcia modelowego przedstawiono na tle analizy istotnych cech gospodarki opartej na wiedzy oraz dostępnych danych Eurostatu i GUSu dotyczących miejsca Polski w europejskiej przestrzeni innowacyjnej. W końcowej części podjęto próbę określenia w jakim stopniu została dokonana weryfikacja empiryczna zaproponowanego ujęcia modelowego lub jest możliwa do zrobienia w toku dalszych badań. Przeprowadzone rozważania wykazały, że istnieje potrzeba weryfikacji empirycznej niektórych elementów modelu, co może stanowić nowe, interesujące pole badawcze w geografii przemysłu.
\end{abstract}

\begin{abstract}
This paper proposes a model approach of contemporary conditions related to a knowledge-based economy (KBE) of the development of industrial enterprises and fundamental implications of their functioning for the formation of this type of economy, in respect of the geographical space. As a result, the article aims to determine the impact of socio-economic, cultural and natural conditions associated to the $\mathrm{KBE}$ on the functioning of industrial enterprises, and on the other hand, to determine to what extent these companies affect the development of the individual elements of geographical space, which are components of KBE. Proposal of the model is shown in the background analysis of the essential features of KBE and available data of Eurostat and Polish Central Statistical Office (GUS) on Poland's position in the European innovation space. Finally, the paper attempts to identify to what extent empirical verification of the proposed model was carried out or whether it is possible to do so during further research. The conducted study has shown that there is a need of empirical verification of some of the model elements, which can be an interesting new field of research in industrial geography.
\end{abstract}

Słowa kluczowe: czynniki produkcji, innowacje, gospodarka oparta na wiedzy, przedsiębiorstwa przemysłowe, Polska, przemysł, Unia Europejska

Key words: factors of production, innovation, knowledge-based economy, industrial enterprises, Poland, industry, the European Union 


\section{WPROWADZENIE}

W nowej fazie rozwoju społeczno-gospodarczego związanej z budową społeczeństwa informacyjnego szczególną rolę odgrywa wiedza, stanowiąca podstawę funkcjonowania współczesnej gospodarki. W tych nowych warunkach rozwoju tradycyjne, podstawowe dotychczas czynniki produkcji: ziemia, kapitał i niżej wykwalifikowane zasoby pracy mają coraz mniejsze znaczenie. Na znaczeniu zyskują natomiast zasoby wiedzy technologicznej niezbędne do procesu produkcji, jak i przedsiębiorczość, traktowana często jako piąty czynnik produkcji i motor wszelkiej innowacyjności. Wpływa to na przemiany zróżnicowania poziomu rozwoju społecznego i gospodarczego poszczególnych państw i regionów świata. Znajduje to także swoje odzwierciedlenie w przemianach roli poszczególnych czynników lokalizacji przedsiębiorstw przemysłowych, na co zwrócili uwagę m.in. T. Stryjakiewicz (2009a) i A. Tobolska (2011). Lokalizacja nowych zakładów, szczególnie sektora zaawansowanej technologii, nawiązuje obecnie bardziej do miejsc stosunkowo tanich pod względem kosztów, ale zarazem zaawansowanych pod względem technologicznych możliwości produkcji, co związane jest w dużej mierze z potencjałem naukowym i intelektualnym zasobów pracy, zdolnych do działalności innowacyjnej. Kierownictwo przedsiębiorstw przemysłowych zdaje sobie bowiem sprawę, że osiąganie i utrzymywanie pozycji konkurencyjnej na rynku wymaga uwzględnienia w strategii funkcjonowania rosnącej roli edukacji i nauki oraz prac badawczo-rozwojowych, co w sposób bezpośredni wpływa na innowacyjność prowadzonej działalności na rożnych płaszczyznach (technologicznej, produktowej, organizacyjnej czy marketingowej). Jak się powszechnie przyjmuje (m.in. OECD 1996; Powell, Snellman 2004; Brinkley 2006; Chojnicki, Czyż 2006, 2008; Leydesdorff 2006; Markowski 2008; Zioło 2008, 2009a; Borowiec, Dorocki, Jenner 2009; Gaczek 2009; Gierańczyk 2010a; Gierańczyk, Rachwał 2012; Rachwał 2012), poziom innowacyjności rozumiany jako zdolność przedsiębiorstw do wdrażania nowych rozwiązań procesowych i organizacyjnych oraz efektywnego wprowadzania nowych bądź znacząco zmodernizowanych produktów na rynek, jest jednym z ważnych czynników rozwoju gospodarki opartej na wiedzy (GOW), a szybkość generowania i dyfuzji innowacji to podstawowe cechy tej gospodarki. Występuje tu pewien rodzaj sprzężenia zwrotnego między innowacyjnością przedsiębiorstw, a wzrostem zapotrzebowania na wiedzę i rozwojem gospodarki na niej opartej. Konkurencja między korporacjami przemysłowymi w zakresie innowacji produktowych powoduje nasilenie się presji na systematyczne przyspieszanie rozwoju technologii i związanego z nią sektora nauki i usług badawczo-rozwojowych. Nasilenie się presji konkurencyjnej w układzie globalnym wymusza zatem na przedsiębiorstwach ciągłe podnoszenie innowacyjności i efektywności produkcji, która odbywa się m.in. poprzez podnoszenie kwalifikacji i wykształcenia pracowników tych przedsiębiorstw, a także wpływa na funkcjonowanie instytucji otoczenia biznesu, szczególnie jednostek badawczo-rozwojowych. W efekcie dochodzi do przyspieszenia rozwoju społeczno-gospodarczego opartego na wiedzy. Tego typu zachowania przedsiębiorstw przemysłowych wynikają z faktu, że zdolność do wytwarzania, gromadzenia i wykorzystywania wiedzy, w tym także w ramach różnorodnych relacji sieciowych, jest podstawą ich przewagi konkurencyjnej we współczesnej gospodarce, na co zwracał uwagę P. Drucker 
(1999), zauważając, że wiedza nie jest co prawda jedynym źródłem ich przewagi, ale za to najważniejszym. Pogląd ten jest powszechnie przyjmowany przez innych autorów (np. Limański 2011; Skrzypek 2011; Makulska 2012).

Ważnym problemem badawczym wydaje się więc zagadnienie roli przedsiębiorstw przemysłowych będących kluczowymi elementami struktury współczesnej GOW, jako podmiotów z jednej strony generujących innowacje, a drugiej zgłaszających zapotrzebowanie na nowe rozwiązania technologiczne, produktowe czy marketingowe i aktywizujących wysokokwalifikowane zasoby kapitału ludzkiego. W artykule zaproponowano więc ujęcie modelowe współczesnych, związanych z GOW uwarunkowań rozwoju przedsiębiorstw przemysłowych oraz podstawowych implikacji ich funkcjonowania dla kształtowania się tego typu gospodarki, w odniesieniu do przestrzeni społeczno-gospodarczej, kulturowej i przyrodniczej wyróżnionych w modelu kształtowania się przestrzeni geograficznej (Zioło 1996, 1999, 2009c). W efekcie zmierzać będzie się do określenia wpływu uwarunkowań społeczno-ekonomicznych, kulturowych i przyrodniczych związanych z GOW na funkcjonowanie przedsiębiorstw przemysłowych, a z drugiej strony do określenia w jakim zakresie te przedsiębiorstwa wpływają na rozwój poszczególnych elementów przestrzeni geograficznej i tym samym komponenty GOW. Propozycję ujęcia modelowego przedstawiono na tle analizy istotnych cech gospodarki opartej na wiedzy oraz dostępnych danych Eurostatu i GUSu dotyczących miejsca Polski w europejskiej przestrzeni innowacyjnej, ze szczególnym uwzględnieniem aktywności związanej z pracami badawczo-rozwojowymi. W końcowej części podjęto próbę określenia, w jakim stopniu została dokonana lub jest możliwa empiryczna weryfikacja zaproponowanego ujęcia modelowego oraz wskazania luk poznawczych w tym zakresie. Artykuł został oparty na bogatej literaturze przedmiotu w celu wskazania na duże zainteresowanie podejmowaną problematyką w naukach geograficzno-ekonomicznych, szczególnie w zakresie analizy uwarunkowań rozwoju przedsiębiorstw w warunkach kształtowania się GOW.

\section{ISTOTA I GŁÓWNE CZYNNIKI KSZTAŁTUJĄCE GOSPODARKĘ OPARTĄ NA WIEDZY}

Choć istnieje wiele definicji gospodarki opartej na wiedzy w bogatej literaturze przedmiotu, to jednak zauważa się brak jednej, powszechnie akceptowanej definicji. Najczęściej autorzy odwołują się do definicji przejętej przez OECD, zaproponowanej przez B. Foray'a oraz D. i B.-Å. Lundvall'a (OECD, 1996), wedle której przyjmuje się, że GOW bazuje bezpośrednio na produkcji, dystrybucji i wykorzystywaniu wiedzy i informacji. W świetle tej koncepcji, GOW oznacza większą zależność rozwoju od wiedzy, informacji i wysokiego poziomu umiejętności oraz rosnące zapotrzebowanie na łatwy dostęp do nich przez przedsiębiorstwa i instytucje sektora publicznego.

Problematyka cech i głównych czynników kształtujących rozwój gospodarki opartej na wiedzy jest przedmiotem zainteresowania wielu autorów. Szczególne miejsce w rozważaniach o istocie tego typu gospodarki zajmuje wiedza, a w szczególności warunki społeczno-ekonomiczne do jej generowania, przechowywania i dystrybuowania (OECD 2006; Brinkley 2006; Zioło 2008), przy czym, jak zauważył A. Kukliński (2001), wiedza sama 
w sobie nie generuje wzrostu gospodarczego, ale musi zostać wykorzystana do produkcji towarów i usług. I. Brinkley (2006) zwraca uwagę na szczególny charakter wiedzy jako ekonomicznego źródła w pełni odnawialnego, które w przeciwieństwie do innych zasobów produkcji, nigdy nie wyczerpuje się w trakcie użytkowania, a w rzeczywistości jej wartość dla rozwoju społeczno-gospodarczego wynika z faktu dzielenia się nią z innymi podmiotami w procesie gospodarowania. Dlatego ważne jest, aby z jednej strony prawo własności intelektualnej chroniło zasoby wiedzy wypracowanej przez poszczególne podmioty, a z drugiej strony warunki prawne powinny być tak kształtowane przez rządy państw, aby zbyt silna ochrona tej własności nie blokowała możliwości dystrybucji i wymiany wiedzy. $\mathrm{Na}$ ten aspekt zwraca uwagę także L. Leydesdorff (2006), który w nawiązaniu do modelu tzw. potrójnej heliksy (Triple Helix Model), podkreśla znaczenie polityki gospodarczej i uwarunkowań prawnych, a także infrastruktury wiedzy dla rozwoju nauki i technologii oraz transferu innowacji. Istotne jego zdaniem są tu więc relacje między trzema głównymi podmiotami w gospodarce opartej na wiedzy: uniwersytetami, przedsiębiorstwami i rządem. Ten punkt widzenia podziela wiele osób, m.in. D. Makulska (2012), która zwraca uwagę na to, że podmiotami, które tworzą warunki sprzyjające powstawaniu i funkcjonowaniu przedsiębiorstw opierających swą przewagę konkurencyjną na wiedzy są: państwo, władze lokalne i regionalne, przedsiębiorstwa oraz środowiska intelektualne i akademickie.

Wiele prac jest poświęconych poszczególnym czynnikom wpływającym na funkcjonowanie nowego typu gospodarki. Przykładowo, M. Borowiec (2008) podkreśla szczególną rolę instytucji szkolnictwa wyższego i struktury kształcenia na poziomie wyższym w tym procesie, na co wcześniej zwracał także uwagę A. Kukliński (2001). K. Stachowiak (2008a, b) na bazie doświadczeń fińskich zwraca uwagę na dużą rolę czynników instytucjonalnych, w tym prowadzonej polityki innowacyjnej i regionalnej, opierającej się w dużej mierze na budowie sieci współpracy innowacyjnych podmiotów gospodarki. Cechą GOW jest zatem układ sieciowy powiązań gospodarczych i społecznych (formalnych i nieformalnych), tworzących charakterystyczne warunki konkurowania i współpracy. Jednocześnie zauważa się „dematerializację” aktywów: wartość rynkowa przedsiębiorstw wyznaczana zaczyna być głównie przez posiadane zasoby (wartości) niematerialne. Do podstawowych czynników związanych z rozwojem GOW zalicza się ponadto powszechnie rozwój technologii informacyjno-komunikacyjnych (por. Leydesdorff 2006; Skrzypek 2011), określany często mianem cyfryzacji, bądź informatyzacji społeczeństwa i gospodarki. Budowa GOW oznacza także kształtowanie się nowej struktury gospodarczej, w której zwiększa się udział przemysłów zaawansowanej technologii i usług o wysokiej wartości dodanej. Proces ten obserwuje się w wielu krajach, w tym także krajach Europy Środkowej i Wschodniej, co było przedmiotem wcześniejszych analiz wielu autorów (m.in. Stryjakiewicz 2002; Stachowiak 2009; Świdurska 2009, 2010; Rachwał 2009, 2010b, 2011b, 2011c; Gierańczyk 2010b; Gurbała 2010; Gierańczyk, Rachwał 2012).

Kompleksowe ujęcie modelowe społecznych i ekonomicznych uwarunkowań rozwoju GOW przedstawił Z. Zioło (2008). Zaproponowany model może zdaniem autora posłużyć nie tylko w określeniu uwarunkowań funkcjonowania GOW, ale także usystematyzowaniu podstawowych elementów strukturalnych oraz określeniu relacji między nimi, wskazaniu 
luk, które należy wypełnić w trakcie dalszych badań oraz wskazaniu na konieczność dalszego poszukiwania nowych cech oraz określania nowych relacji między nimi. Do najważniejszych czynników ekonomicznych warunkujących rozwój GOW zaliczył on wartość potencjału ekonomicznego oraz wartość środków kierowanych na badania i rozwój, natomiast do czynników społeczno-kulturowych: jakość decydentów, zasoby intelektualne (poziom wiedzy), poziom edukacji, aspiracje, plany i cele życiowe, świadomość społeczną, kulturową i polityczną oraz postawy przedsiębiorcze w społeczeństwie. W efekcie w GOW kształtuje się nowy rynek pracy, którego cechą jest wysoki udział pracowników wiedzy (knowledge workers) - wysokiej klasy specjalistów w strukturze zatrudnienia i wyłanianie się nowego typu przedsiębiorstwa, posiadającego - jak zauważa E. Skrzypek (2011) - cechy organizacji uczącej się, określanego mianem przedsiębiorstwa wiedzy.

\section{ZDOLNOŚĆ ADAPTACJI PRZEDSIĘBIORSTW PRZEMYSŁOWYCH}

DO WARUNKÓW GOSPODARKI OPARTEJ NA WIEDZY

Należy jednak podkreślić, że nie wszystkie przedsiębiorstwa przemysłowe stają się przedsiębiorstwami wiedzy, zdolnymi do funkcjonowania w warunkach „nowej gospodarki”. Zdolność ta zależy od szeregu uwarunkowań wewnętrznych, tkwiących w strukturze samego przedsiębiorstwa, do których należy zaliczyć przede wszystkim:

- potencjał ekonomiczny przedsiębiorstwa i jego zdolność do trwałego finansowania działalności innowacyjnej, w tym prac badawczo-rozwojowych,

- lokalizację przedsiębiorstwa z punktu widzenia kształtowania efektywnych powiązań kooperacyjnych i budowy relacji sieciowych,

- umiejętności zarządzania wiedzą oraz kultura organizacyjna przedsiębiorstwa, nastawiona na generowanie, przechowywanie i wykorzystywanie wiedzy w procesach technologicznych i działalności marketingowej oraz sprzyjająca przekazowi wiedzy między pracownikami przedsiębiorstwa,

- jakość kadry zarządzającej i jej świadomość wyzwań związanych z budową gospodarki opartej na wiedzy,

- przedsiębiorczość i innowacyjność pracowników (od kadry menedżerskiej po pracowników szeregowych) i ich chęć ciągłego dokształcania się i samorozwoju (uczenie się przez całe życie w ramach systemu tzw. kształcenia ustawicznego).

Na szczególną uwagę wśród tych uwarunkowań zasługują zasoby kapitału ludzkiego, zarówno będące w bezpośredniej dyspozycji przedsiębiorstwa (pracownicy) jak i dostępne na rynku pracy. To właśnie te zasoby, o odpowiednim poziomie wykształcenia i kompetencji, tj. wyposażenia w wiedzę, umiejętności i przedsiębiorcze, innowacyjne postawy, są - jak wskazuje wielu autorów - podstawą przewagi konkurencyjnej przedsiębiorstw i w konsekwencji gospodarek układów przestrzennych różnej skali (Lee, Florida, Acs 2004; Acs 2006; Audtretsch, Keilbach, Lehmann 2006; Zioło 2006, 2007, 2009a, 2012a, 2012b; Beugelsdijk 2007; Jarczewski 2007; Dominiak, Rekowski 2008; Valliere, Peterson 2009; Kurek, Rachwał 2010, 2011; Rachwał 2010a; Zioło, Rachwał 2012). A. Koźmiński (2002) przyjmuje nawet, 
że rozwój przedsiębiorstw opartych na wiedzy jest w znacznej mierze efektem przedsiębiorczości. E. Skrzypek (2011) podkreśla natomiast dużą rolę umiejętności zarządzania wiedzą w przedsiębiorstwie. Jej zdaniem polega to na tym, że wszystkie procesy winny być postrzegane jako związane z wiedzą, co oznacza, że zawierają w sobie elementy twórczości i praktycznego stosowania wiedzy, by organizacja mogła przetrwać i rozwijać się. W takim przedsiębiorstwie występują wszystkie kluczowe procesy związane z wiedzą, tj. pozyskiwanie, lokalizowanie, zachowywanie, wykorzystywanie, dzielenie się, rozpowszechnianie oraz rozwijanie wiedzy i tworzą one spójny system zarządzania wiedzą, co powinno prowadzić do wzrostu innowacyjności i podniesienia poziomu konkurencyjności przedsiębiorstwa (Skrzypek 2011). Na dużą rolę zarządzania wiedzą w przedsiębiorstwach przemysłowych zwracają uwagę także inni autorzy (np. Zavloschi-Dunareanu 2013).

Należy podkreślić, że w przypadku tzw. starych przedsiębiorstw przemysłowych, funkcjonujących w warunkach gospodarki centralnie sterowanej w Polsce i innych krajach transformujących swoje gospodarki, proces przemian w kierunku przedsiębiorstwa wiedzy z reguły musi być poprzedzony jego adaptacją do warunków gospodarki rynkowej, związaną z procesami restrukturyzacji, co było przedmiotem wcześniejszych prac (m.in. Stryjakiewicz 1999; Rachwał 2006a, 2006b; Tobolska 2006).

\section{PozIOM INNOWACYJNOŚCI POLSKI NA TLE INNYCH KRAJÓW}

JAKO WSKAŹNIK KLIMATU DLA INWESTYCJI I DZIAŁAŃ INNOWACYJNYCH

W procesie kształtowania GOW istotne znaczenie ma klimat dla innowacyjności. A. Koźmiński (2002) przyjmuje, że gospodarki oparte na wiedzy muszą stwarzać warunki sprzyjające inicjatywie i przedsiębiorczości, szczególnie tzw. przedsiębiorczości intelektualnej, realizowanej przez twórców oryginalnej wiedzy, a w tego typu gospodarkach wysoki procent PKB przeznaczany jest na edukację, badania naukowe, usługi intelektualne oraz na produkty i usługi informacyjno-komunikacyjne. Niestety Polska na tle innych państw Unii Europejskiej jest klasyfikowana jako jeden z krajów o najniższych nakładach na naukę i szkolnictwo wyższe oraz prace badawczo-rozwojowe. $Z$ drugiej strony na uwagę zasługuje fakt, że na naszym rynku występują stosunkowo dobre zasoby kapitału intelektualnego i potencjału ludzkiego dla prac badawczo-rozwojowych, w tworzeniu którego miał swój udział boom w szkolnictwie wyższym w ostatnich latach. Niestety, w tym samym czasie następował znaczący spadek nakładów na kształcenie jednego studenta, tak że są one w Polsce kilkunastokrotnie mniejsze niż w bogatych krajach Unii Europejskiej i kilkadziesiąt razy mniejsze niż w najlepszych uniwersytetach amerykańskich (Koźmiński 2002). Kolejne reformy systemu edukacji, w tym szkolnictwa wyższego, nie zmieniły tego stanu rzeczy. Do tego dochodzi fakt, że w Polsce wiele przedsiębiorstw należy do międzynarodowych korporacji, które często z założenia prowadzą prace badawczo-rozwojowe w swoich macierzystych (rdzeniowych) krajach i często wygaszają działalność innowacyjną w przejmowanych przedsiębiorstwach polskich. 
Sytuacja ta musiała się niestety odbić na wyjątkowo niskich wskaźnikach innowacyjności Polskiej gospodarki na tle UE, co było przedmiotem zainteresowania m.in. P. Nowaka (2011). Zwrócił on uwagę nie tylko na niską pozycję Polski w tym zakresie w stosunku do innych krajów, ale także na fakt, że słabą pozycję Polski pogarsza niższe tempo wzrostu innowacyjności aniżeli w innych krajach regionu. Większość krajów, takich jak Rumunia, Bułgaria, Estonia, Czechy i Łotwa, nadrabia dystans dzielący je od czołówki europejskiej o wiele szybciej niż my. W efekcie szczegółowej analizy konkluduje, że polska gospodarka należy do najmniej innowacyjnych gospodarek Europy (Nowak 2011). Jest to zdanie, w świetle innych rankingów i analiz innowacyjności, które przywołuje m.in. Z. Zioło (2012), w pełni uprawnione. Najnowszy raport Komisji Europejskiej w tym zakresie - Innovation Union Scoreboard 2013, wskazuje na pogarszającą się sytuację Polski w stosunku do innych krajów, która wypadła z grupy „umiarkowanych innowatorów” (moderate innovators) do najniższej grupy, eufemistycznie określanej jako „skromnych innowatorów” (modest innovators) - ryc. 1. Dane w układzie regionalnym wskazują, że poza województwem mazowieckim, należącym do grupy „umiarkowanych innowatorów”, pozostałe polskie regiony zostały zaliczone do najsłabszej grupy.

Równie niekorzystnie wygląda sytuacja w zakresie relacji nakładów na prace badawczo-rozwoje w stosunku do PKB (ryc. 2). W przypadku liderów - państw skandynawskich (Finlandia, Szwecja, Dania) wskaźnik ten przekracza 3\%, czyli minimalny poziom zakładany w Strategii Lizbońskiej. W Polsce jest on około 4-krotnie niższy (0,74\% PKB). Na końcowe pozycje Polski pod względem wskaźników finansowania działalności naukowo-badawczej zwracał uwagę także Z. Zioło (2012), który konstatuje, że w efekcie, przy stosunkowo dobrej kadrze naukowej, wiele dobrych polskich pomysłów wędruje za granicę, a nie zostaje zrealizowanych w kraju, natomiast założenia Ministerstwa Gospodarki, że w 2020 r. Polska znajdzie się w grupie krajów mocno innowacyjnych, jest mało realne, gdyż nakłady na badania i rozwój musiałyby się zwiększyć ponad dwukrotnie, tj. do ok. 1,7\% PKB, tak jak w przypadku Wielkiej Brytanii czy Holandii.

Polskę cechuje też niski odsetek przedsiębiorstw wprowadzających innowacje (zarówno procesowe, jak i produktowe oraz marketingowe). Stanowią one poniżej 30\% ogółu, przy średniej dla UE powyżej 50\%. Polska w tym rankingu (bez Grecji) zajmuje przedostatnie miejsce. Konsekwencją takiego obrazu Polski na tle innych krajów UE może być postrzeganie tego kraju jako mało atrakcyjnego dla lokalizacji nowych inwestycji, szczególnie przemysłów zaawansowanych technologicznie i usług o wysokiej wartości dodanej oraz prowadzenia prac badawczo-rozwojowych.

\section{MODEL FUNKCJONOWANIA PRZEDSIĘBIORSTW PRZEMYSŁOWYCH W WARUNKACH GOSPODARKI OPARTEJ NA WIEDZY}

W nawiązaniu do modelu funkcjonowania przestrzeni geograficznej Z. Zioło (1996, 1999, 2009c), w tym ujęciu powiązań przedsiębiorstwa przemysłowego z elementami przestrzeni geograficznej (Zioło 2003) w proponowanym modelu przyjmuje się, że 


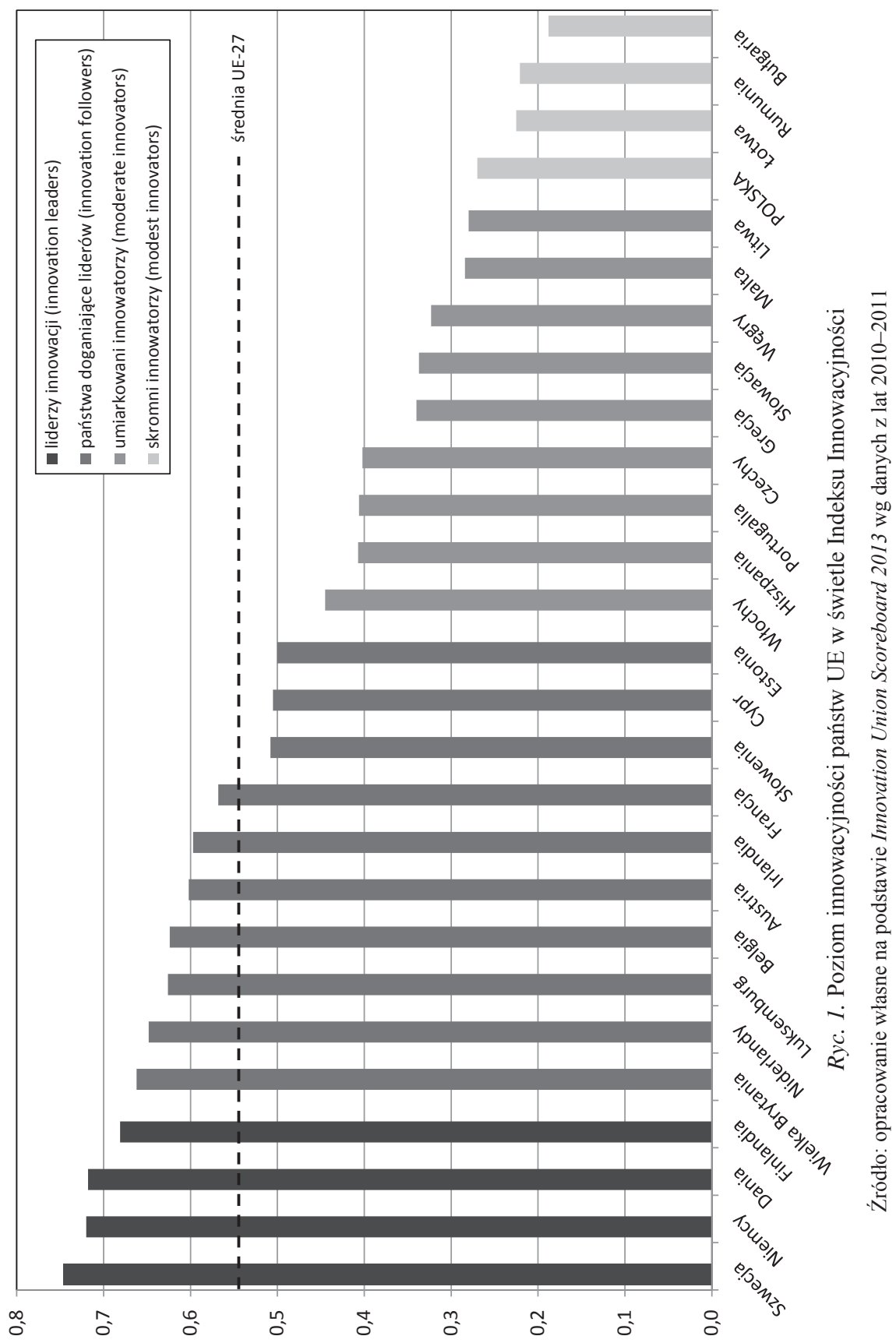




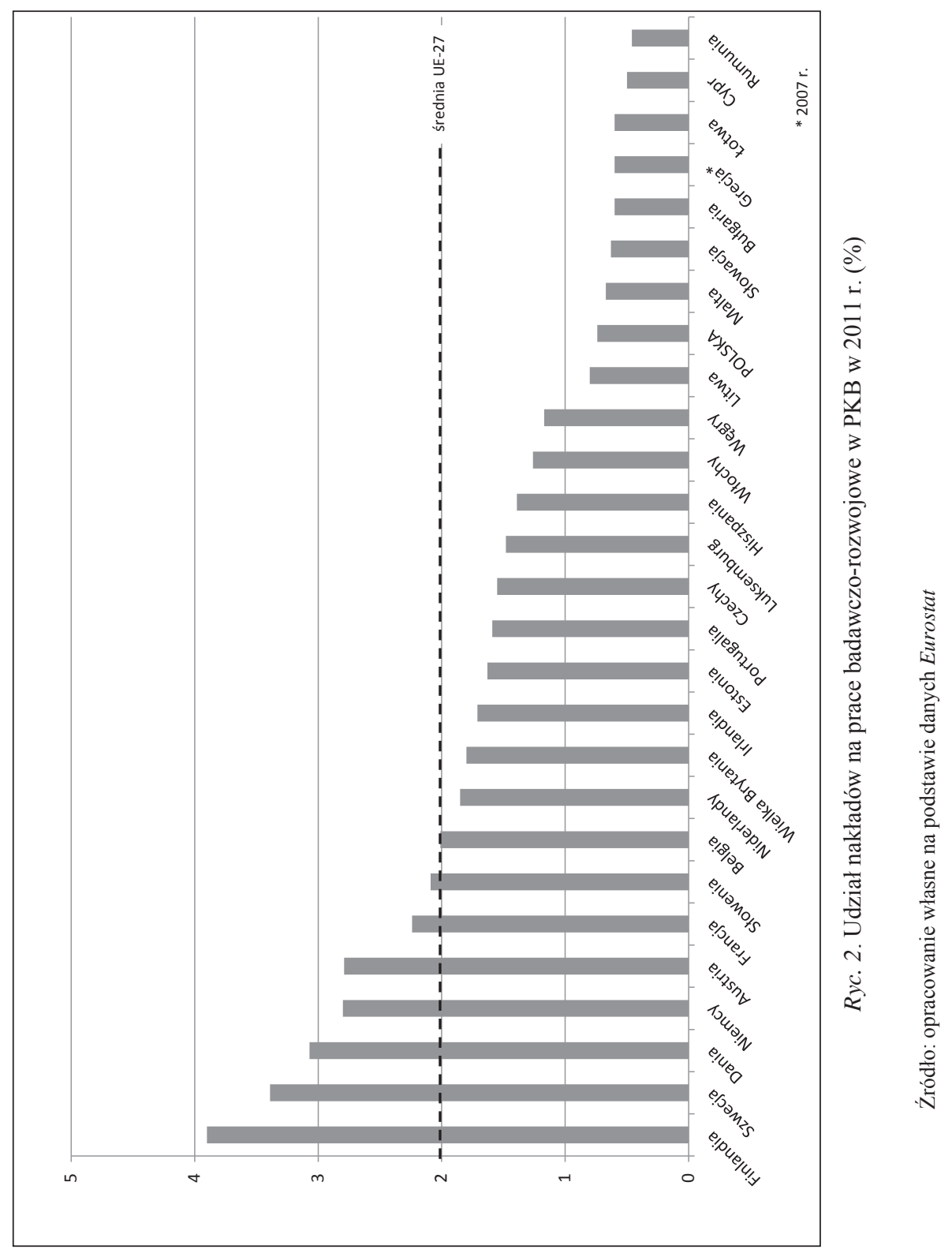




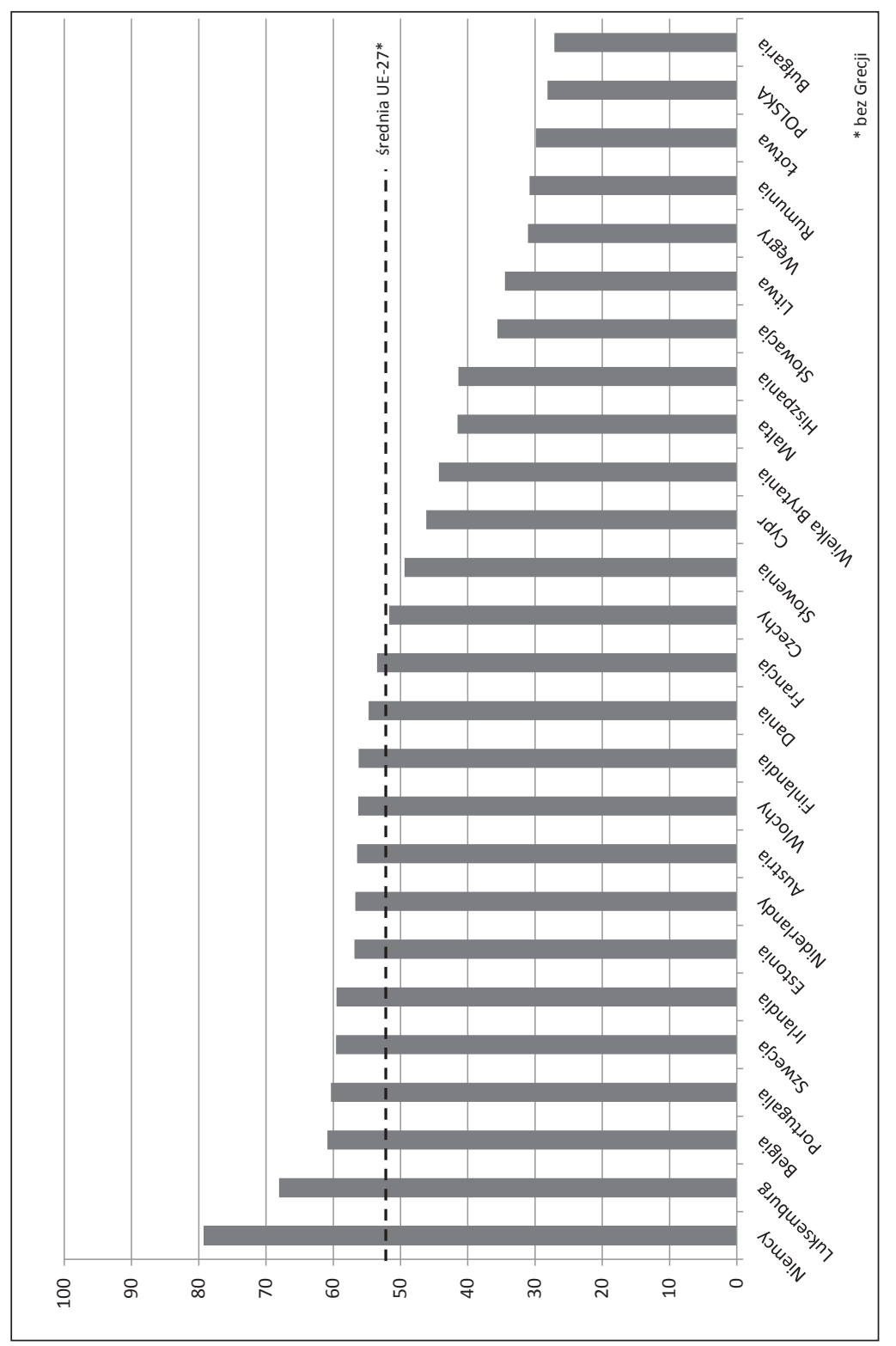

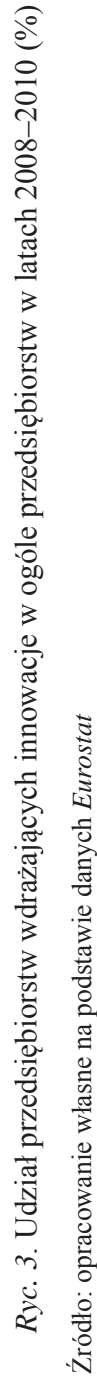


funkcjonowanie przedsiębiorstw przemysłowych kształtowane jest przez ogólne uwarunkowania rozwoju cywilizacyjnego, które znajdują swoje odzwierciedlenie w oddziaływaniu poszczególnych elementów przestrzeni geograficznej: gospodarczych, społeczno-politycznych, kulturowych i przyrodniczych (ryc. 4). Na jego funkcjonowanie mają także wpływ specyficzne uwarunkowania krajowe, np. w Polsce związane głównie ze zmianą instrumentów administracyjno-prawnych $\mathrm{w}$ procesie transformacji gospodarczej i integracji $\mathrm{z}$ Unią Europejską. Między ogólnymi uwarunkowaniami rozwoju a specyficznymi uwarunkowaniami krajowymi występują współzależności, co szczególnie widać w warunkach globalizującej się gospodarki i co silnie uwydatnił ostatni kryzys gospodarczy.

Przyjmując założenie, że zarząd i pracownicy przedsiębiorstwa przemysłowego są świadomi warunków gospodarczych, w jakich ono działa i funkcjonuje jako przedsiębiorstwo wiedzy, oddziałuje ono na poszczególne elementy przestrzeni geograficznej przyczyniając się do rozwoju GOW. Rozwój tej gospodarki z kolei wpływa na zmianę poszczególnych elementów przestrzeni, modyfikując wcześniej ukształtowane uwarunkowania rozwoju, występuje tu więc rodzaj sprzężenia zwrotnego. Warto również podkreślić, że poszczególne elementy przestrzeni (społeczno-gospodarcze, kulturowe, przyrodnicze) oddziałują także na siebie, tworząc relacje pasywne i aktywne (por. Zioło 2003, 2009c).

Analizując głębiej te ogólne zależności można wskazać bardziej szczegółowo oddziaływanie poszczególnych elementów (ryc. 5). W oparciu o analizę literatury przedmiotu, jak i wyniki wcześniejszych badań własnych nad funkcjonowaniem przedsiębiorstw przemysłowych, czynniki zewnętrzne wpływające na rozwój przedsiębiorstw przemysłowych (traktowanych jako podstawowe elementy struktury GOW), obejmujące zarówno impulsy płynące z otoczenia międzynarodowego jak i krajowego, są następujące:

- procesy globalizacji gospodarki związane z procesami koncentracji kapitału i przepływów bezpośrednich inwestycji zagranicznych, co nasila presję konkurencyjną korporacji międzynarodowych, które w swojej działalności w szerokim zakresie wykorzystują wiedzę jako podstawowy czynnik innowacyjności,

- priorytety polityki gospodarczej (w tym polityki przemysłowej oraz polityki na rzecz przedsiębiorczości i innowacyjności) oraz znaczenie nauki i szkolnictwa w tej polityce, prowadzonej zarówno na szczeblu międzynarodowym (różnego typu organizacje i porozumienia międzynarodowe, ugrupowania integracyjne, np. UE itp.) jak i krajowym,

- rozwój sektora nauki, w tym badań podstawowych i stosowanych oraz szkolnictwa wszystkich szczebli, szczególnie na poziomie wyższym,

- rosnąca rola wiedzy i dostępność do wyników badań zagranicznych i krajowych ośrodków badawczych oraz możliwość transferu know-how z innych przedsiębiorstw (zakup licencji, przekazanie w ramach grupy kapitałowej itp.), a także działalność organizacji i instytucji międzynarodowych wspierających rozwój badań naukowych i współpracy przedsiębiorstw w zakresie innowacyjności (np. instytucje UE),

- szybki postęp technologiczny i dobrze rozwinięta infrastruktura, szczególnie informacyjna (ICT),

- struktura rynku pracy, w tym dostępność do wysokokwalifikowanych kadr naukowo-badawczych i menedżerskich oraz rosnąca rola tzw. klasy kreatywnej, 
- kształtowanie się społeczeństwa informacyjnego,

- poziom kapitału ludzkiego, w tym wzrost aspiracji i zmiana postaw jednostek oraz kapitału społecznego, wpływającego na procesy budowy sieci i kooperacji oraz tzw. kultura przedsiębiorczości tworzące klimat dla rozwoju innowacyjności,

- przedsiębiorczość jednostek.

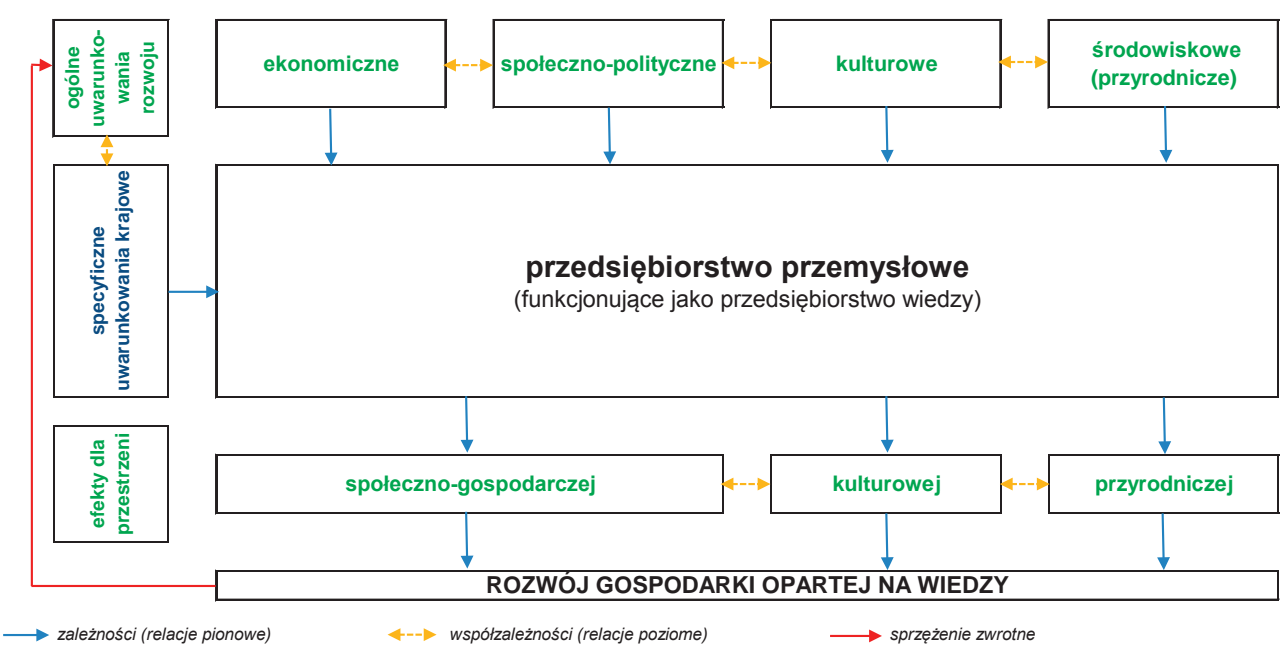

Ryc. 4. Zarys modelu funkcjonowania przedsiębiorstwa przemysłowego w warunkach GOW

Źródło: opracowanie własne

Warto zauważyć także znaczenie warunków środowiskowych, które tradycyjnie rozpatrywane były z reguły głównie od strony bazy surowcowej (dostępność do surowców mineralnych i ich wyczerpywalność) i wydawało się, że - ze względu na malejącą rolę bazy surowcowej jako czynnika lokalizacji - wpływ tych czynników będzie coraz mniejszy. W ostatnim jednak czasie coraz większe znaczenie dla funkcjonowania przedsiębiorstw przemysłowych ma wdrażana w wielu krajach koncepcja ekorozwoju, z którą związana jest większa świadomość ekologiczna społeczeństw i decydentów oraz z reguły bardziej rygorystyczne wymogi ochrony środowiska. Coraz większą uwagę przywiązuje się do wyczerpywalności zasobów naturalnych, co wymusza na przedsiębiorstwach poszukiwanie nowych rozwiązań technologicznych (np. innowacje w silnikach samochodowych) oraz ogranicza dostępność do przestrzeni, wskutek czego korzyści aglomeracji przekształcają się bardzo często w niekorzyści aglomeracji, co powoduje konieczność innego niż tradycyjne spojrzenia na czynniki lokalizacji.

Do specyficznych uwarunkowań krajowych należy zaliczyć przede wszystkim wdrażanie nowych mechanizmów administracyjno-prawnych, związanych w warunkach polskich z procesem transformacji gospodarczej i integracją z UE, w tym rozwiązań podatkowych i instytucjonalnych współpracy przedsiębiorstw przemysłowych z instytucjami rządowymi i otoczenia biznesu. Nie należy jednak pomijać faktu, że przedsiębiorstwa te funkcjonują w ukształtowanych wcześniej formach koncentracji przemysłu (skupienia, zespoły, 
kombinaty, ośrodki, okręgi przemysłowe), w ramach których występują określone powiązania. W ostatnim czasie pojawiają się jednak możliwości kształtowania się nowych form, w tym inicjatyw klastrowych i innych powiązań sieciowych z pomocą środków publicznych (z funduszy krajowych lub unijnych), choć często określa się tym mianem tradycyjne, wcześniej wyodrębnione formy koncentracji przemysłu. Istotnym czynnikiem są tutaj również nakłady finansowe na działalność innowacyjną, w tym działalność badawczo-rozwojową ze środków publicznych, przekazywane w ramach polityki naukowej państwa.

Na funkcjonowanie przedsiębiorstw przemysłowych duży wpływ ma więc także dostępność do zewnętrznych źródeł zasilania finansowego prac badawczo-rozwojowych, w tym tzw. kapitału wysokiego ryzyka, „miękkich” (o obniżonym oprocentowaniu) kredytów oraz bezzwrotnego dofinansowania tych prac (np. ze środków UE), na co wpływ mają także fazy cyklu koniunkturalnego oraz podejmowane działania państwa w fazie recesji na rzecz przeciwdziałania jej skutkom. W ostatnich latach silnie zaznacza się zatem wpływ czynników związanych z ogólnoświatowym kryzysem gospodarczym, w tym kryzysem finansowym w strefie euro, co może wpływać na ograniczenie działalności inwestycyjnej oraz innowacyjnej, m.in. w zakresie badań i rozwoju, ze względu na niepewność przedsiębiorstw w odniesieniu do przyszłych dochodów i brak środków obrotowych. Warto jednak podkreślić, że wpływ ten w wielu przypadkach jest ograniczony, co sprawia, że mamy do czynienia raczej z dekoniunkturą czy spowolnieniem gospodarczym. Ponadto wpływ tego czynnika należy rozpatrywać w perspektywie krótko- lub co najwyżej średniookresowej. Wpływ kryzysu na przedsiębiorstwa przemysłowe był przedmiotem wcześniejszej pracy (Rachwał 2011), a także prac innych autorów (np. Kitowski 2009, 2011; Repetowski 2010; Boguś 2011; Bonar 2011; Czapliński 2011; Nowak 2011; Šerý 2011; Szymańska 2011; Wójtowicz 2011; Zioło 2011). Ostatnie raporty OECD (2012) wskazują natomiast, że:

- kryzys wpłynął negatywnie na innowacyjność przedsiębiorstw oraz prace badawczo-rozwojowe w każdym kraju;

- ujawnił słabości (o genezie przedkryzysowej) niektórych krajów (np. Grecji), sektorów (np. sektor motoryzacyjny) i rodzajów innowacji (np. innowacje finansowe);

- choć sytuacja w wielu krajach OECD (północna Europa, Japonia i Stany Zjednoczone) poprawiła się nieco, ich przyszłość w zakresie innowacji pozostaje niepewna; będzie zależeć od warunków makroekonomicznych, ale również od ich zdolności do utrzymania innowacji jako priorytetu polityki;

- ograniczenie finansowania inwestycji, w tym innowacyjnych, przez instytucje sektora finansowego nie mogą być jedynym wytłumaczeniem spadku innowacyjności.

Raport ten wskazuje także, że wiele krajów wdrożyło politykę wspierania innowacji w czasie kryzysu, a odpowiedzią rządów na kryzys były głównie inwestycje w infrastrukturę dla innowacji i zapewnienie środków finansowych dla przedsiębiorstw do prowadzenia działań, co należy ocenić jako zjawisko pozytywne. Niestety w Polsce brak jest zdecydowanych działań tego typu.

Warto także podkreślić szczególną rolę klasy kreatywnej i postaw przedsiębiorczych w funkcjonowaniu przedsiębiorstw, jako ważnych czynników wpływających na ich funkcjonowanie w warunkach GOW. Na dużą rolę sektora kreatywnego (nazywanego też sektorem 
kreatywnej wiedzy) na przykładzie Poznania zwracali uwagę - w wyniku wieloletnich badań w ramach międzynarodowego projektu ACRE - T. Stryjakiewicz, M. Męczyński i K. Stachowiak (2009). Podkreślają oni specyficzne preferencje lokalizacyjne klasy twórczej w odniesieniu do miejsc zamieszkania i miejsc pracy, które wykazują wyraźną tendencję do koncentracji przestrzennej w tzw. nowych przestrzeniach przemysłowych, których przykładem jest Dolina Krzemowa, oraz regionach metropolitalnych. Szczegółowe analizy tych tendencji przedstawiono w szeregu publikacji (Stryjakiewicz, Męczyński, Stachowiak 2008, 2009; Stryjakiewicz, Męczyński 2010; Stryjakiewicz, Stachowiak 2010; Stryjakiewicz i in. 2007, 2010; Stryjakiewicz 2008, 2009b). Na marginesie należy dodać w nawiązaniu do najnowszych doniesień naukowych (Gabe, Florida, Mellander 2013), że klasa kreatywna jest mniej narażona na bezrobocie, a posiadanie zawodu kreatywnego sprzyja zachowaniu zatrudnienia w warunkach kryzysu gospodarczego. Zaobserwowane wzory zachowań w Stanach Zjednoczonych świadczą zdaniem autorów tych badań o korzystnych zmianach w strukturze gospodarczej, które sprzyjają rozwojowi bazujących na wiedzy sektorów kreatywnych. Nie ulega wątpliwości, że również w warunkach recesji lepiej będą radzić sobie przedsiębiorstwa zatrudniające kreatywnych pracowników wiedzy lub współpracujące z firmami tego sektora.

Szczególną rolę w rozwoju społeczno-gospodarczym i procesach innowacyjnych odgrywa przedsiębiorczy człowiek, na co zwracali szczególną uwagę m.in. T. Rachwał (2010a), S. Kurek i T. Rachwał (2010, 2011) i Z. Zioło (2006, 2007, 2009a, 2012). Należy w pełni zgodzić się ze stanowiskiem Z. Zioło (2012: 29-30), że „podstawowym czynnikiem pobudzającym rozwój innowacyjności jest odpowiednio wyedukowany człowiek o cechach przedsiębiorczych, który ciągle poszukuje nowych rozwiązań w zakresie wytwarzania nowych i doskonalenia już istniejących, coraz bardziej konkurencyjnych produktów, a także przygotowany do wdrażania nowych organizacji produkcji i życia społecznego". Dlatego rządy poszczególnych państw coraz większą wagę w polityce gospodarczej przywiązują do przedsiębiorczości jako istotnego czynnika wzrostu ekonomicznego (Acs 2006; Acs, Szerb 2007; Audretsch, Keilbach, Lehmann 2006; Wennekers, Thurik 1999; Zioło 2006, 2007) a jej miejsce w kształceniu na wszystkich poziomach edukacji staje się coraz bardziej znaczące (Berger i in. 2012; Bieniok 2007; Cieślik 2007; Borowiec, Rachwał 2011; Kurek, Rachwał, Szubert 2012a, 2012b; Pietrzykowski 2011; Rachwał 2006c; Wach 2007; Zioło 2012b). Zauważa się także coraz większe jej znaczenie w badaniach geograficznych (Zioło, Rachwał 2012). 


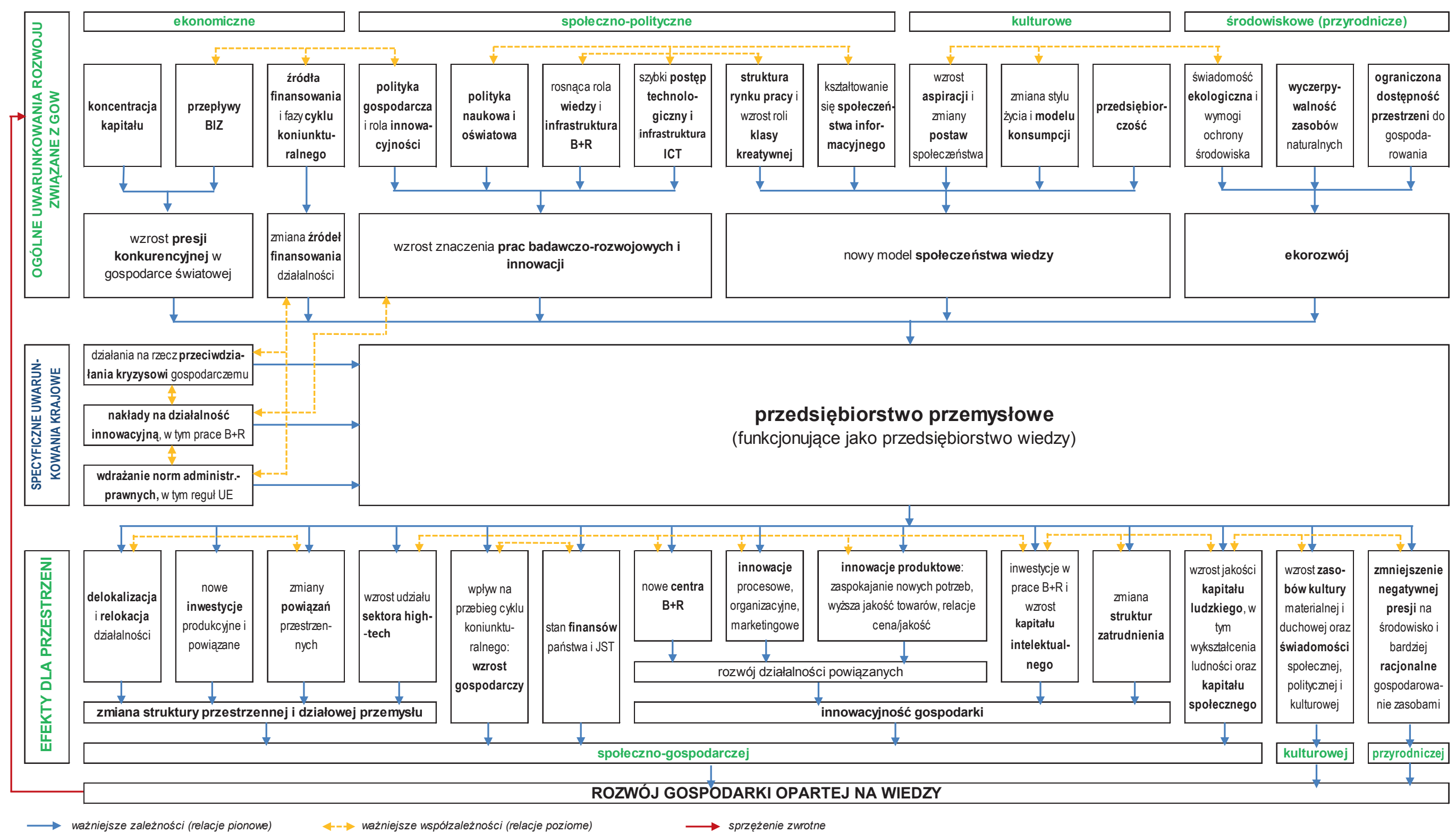

Ryc. 5. Model funkcjonowania przedsiębiorstwa przemysłowego w warunkach GOW

Źródło: opracowanie własne 
W proponowanym ujęciu modelowym uchwycono nie tylko ważniejsze uwarunkowania, ale także efekty działalności przedsiębiorstw przemysłowych dla poszczególnych kategorii przestrzeni geograficznej i w konsekwencji rozwoju GOW. Należy przy tym zauważyć, że choć w literaturze przedmiotu, jak wykazano powyżej, stosunkowo dużo miejsca poświęca się analizie wpływu różnego typu uwarunkowań społeczno-kulturowych i ekonomicznych związanych z rozwojem gospodarki opartej na wiedzy na funkcjonowanie przedsiębiorstw, to stosunkowo mniej uwagi poświęcane jest relacjom aktywnym, czyli funkcjom przedsiębiorstw przemysłowych w rozwoju gospodarki opartej na wiedzy. Z jednej strony gospodarka ta wymusza więc określone zmiany w funkcjonowaniu przedsiębiorstw przemysłowych, mające na celu dostosowanie ich strategii działania do nowych wyzwań, z drugiej zaś strony to właśnie te przedsiębiorstwa generują impulsy wpływające na jej rozwój. Trzeba bowiem podkreślić, że przedsiębiorstwa te z jednej strony mogą prowadzić zaawansowane prace badawczo-rozwojowe nad nowymi technologiami produkcji i produktami i tym samym być podmiotami generującymi innowacje i wpływającymi na wzrost zasobów wiedzy technologicznej, z drugiej zaś strony wiele z nich zgłasza zapotrzebowanie na gotowe rozwiązania innowacyjne, sprzedawane w postaci np. licencji, patentów przez inne firmy, co wpływa na zwiększenie źródeł zasilania finansowego prac z nimi związanych. Generować to może efekty mnożnikowe w rozwoju lokalnym i regionalnym, a więc rozwój działalności z reguły dużo większy niż w przypadku przedsiębiorstw sektora usługowego, oraz w istotny sposób pobudzać działy usług kluczowe w gospodarce opartej na wiedzy do dynamicznego rozwoju. Wynika to zarówno z relatywnie dużego potencjału przedsiębiorstw przemysłowych, jak i z pełnionych przez nie ważnych funkcji ekonomiczno-społecznych związanych z aktywizacją rynku pracy dla wysokokwalifikowanych specjalistów oraz zapotrzebowaniem na praktyczne zastosowanie wyników prowadzonych badań naukowych (Rachwał 2012). W efekcie, dzięki wdrażaniu innowacji procesowych, produktowych, organizacyjnych i marketingowych, a także związanych z nimi inwestycji w prace B+R i wzrost kapitału intelektualnego oraz zmian struktur zatrudnienia, podnosi się poziom innowacyjności gospodarki.

Przemiany technologiczne i presja konkurencyjna w zakresie innowacji wpływają na procesy delokalizacji i relokacji działalności, w wyniku poszukiwania najbardziej korzystnych miejsc do lokalizacji produkcji, z czym związana jest zmiana powiązań przestrzennych przedsiębiorstw przemysłowych. W efekcie dochodzi do zmian struktury przestrzennej przemysłu. Wzrost działalności innowacyjnych prowadzi z kolei do zwiększenia się znaczenia przemysłów zaawansowanej technologii, co prowadzi do przemian struktury działowej przemysłu, na co zwracano uwagę we wcześniejszych pracach (Rachwał 2010b, 2011b).

Przedsiębiorstwa przemysłowe, funkcjonujące jako przedsiębiorstwa wiedzy, oddziałują także na przebieg cyklu koniunkturalnego przyspieszając procesy wchodzenia w fazę wzrostu gospodarczego oraz stan finansów państwa i jednostek samorządu terytorialnego, co wynika z reguły z ich wyższej rentowności i tym samym większego ich udziału w dochodach podatkowych jednostek sektora finansów publicznych. Efektem ich rozwoju jest także wzrost jakości kapitału ludzkiego i społecznego, w tym podniesienia poziomu wykształcenia ludności. Zaznacza się także wpływ na przestrzeń kulturową, szczególnie poprzez oddziaływanie na sektory kreatywne (np. design przedmiotów użytkowych, w efekcie 
czego następuje wzrost zasobów kultury) oraz przyrodniczą, polegający głównie na zmniejszeniu negatywnej presji na środowisko i bardziej racjonalnym gospodarowaniu zasobami. W proponowanym modelu przyjmuje się, że wszystkie te elementy, także związane z przestrzenią kulturową i przyrodniczą, stanowią komponent GOW. W wyniku jej rozwoju następuje sprzężenie zwrotne, a więc zmiana pierwotnych uwarunkowań, przy czym oznacza to podniesienie na nowy, wyższy poziom organizacji poszczególnych struktur elementów przestrzeni geograficznej.

\section{ZAKOŃCZENIE}

Jak się wydaje, zaproponowane ujęcie modelowe pozwala na usystematyzowane określenie uwarunkowań funkcjonowania przedsiębiorstw przemysłowych i ich wpływu na rozwój GOW, uchwycenie podstawowych relacji między elementami strukturalnymi oraz wskazanie luk poznawczych możliwych do wypełnienia w trakcie dalszych rozważań teoretycznych i analiz wyników badań empirycznych.

Wskazane by było, aby model poddany był weryfikacji empirycznej, co zostało częściowo dokonane w wyniku badań własnych i innych autorów. W świetle literatury przedmiotu oraz badań własnych należy wnosić, że stosunkowo dobrze zostały określone w ujęciach teoretycznych i badaniach empirycznych czynniki wpływające na funkcjonowanie przedsiębiorstw przemysłowych w warunkach GOW, co wykazano w pierwszej części artykułu, przy czym stosunkowo najmniej został rozpoznany wpływ aspiracji i zmiany postaw społeczeństwa oraz przedsiębiorczości jednostek na funkcjonowanie przemysłu, choć zostało to zarysowane w pracach Z. Zioło (2012) oraz Z. Zioło i T. Rachwała (2012) i wstępnie podjęte w toku badań własnych.

Można wnosić, że nieco słabiej zostały zbadane empirycznie mechanizmy wpływu funkcjonowania przedsiębiorstw przemysłowych na GOW. W toku dotychczasowych badań indywidualnych (głównie na przykładzie przedsiębiorstw polskich, ze szczególnym uwzględnieniem Polski południowo-wschodniej) i zespołowych, zweryfikowano empirycznie, przynajmniej częściowo, wpływ na: kształtowanie się nowej struktury przestrzennej przemysłu (relokacje, nowe inwestycje, zmiany powiązań przestrzennych w zakresie zaopatrzenia i zbytu, zmiany udziału przemysłu high-tech), zmiany struktury branżowej (działowej) przemysłu (w oparciu o strukturę zatrudnienia i wartość produkcji sprzedanej przemysłu wg działów PKD/NACE), innowacje procesowe (technologii produkcji) i produktowe (zmiany asortymentu), inwestycje w działalność innowacyjną, w tym w prace B+R, zmiany struktur zatrudnienia, wzrost jakości kapitału ludzkiego, zmniejszenie negatywnej presji na środowisko. Analiza prac badawczych innych autorów wskazuje natomiast, że dokonano ponadto przynajmniej częściowej weryfikacji empirycznej wpływu funkcjonowania przedsiębiorstw przemysłowych na: przebieg cyklu koniunkturalnego (w tym wzrost gospodarczy), gospodarkę finansową państwa i jednostek samorządu terytorialnego, innowacje organizacyjne i marketingowe czy wzrost kapitału intelektualnego. Należy jednak zwrócić uwagę, że bardzo często, ze względu na ograniczoną dostępność danych statystycznych nie 
wyodrębnia się przedsiębiorstw przemysłowych lub pomija niektóre aspekty, skupiając się na tych, dla których są dostępne dane (np. zgłaszane patenty jako efekty innowacyjnych prac $\mathrm{B}+\mathrm{R})$. W niewielkim stopniu został przebadany wpływ na wzrost zasobów kultury oraz świadomości społecznej, politycznej i kulturowej. Jak się więc wydaje, brakuje też w szerszym ujęciu niż studium przypadku analiz wpływu na wzrost jakości kapitału ludzkiego, w tym wykształcenia ludności. Konieczne może się okazać także dalsze poszukiwanie czynników kształtujących rozwój przedsiębiorstw przemysłowych w warunkach GOW i ewentualnie nieuwzględnionych w modelu kierunków oddziaływania.

Pełne rozpoznanie roli przedsiębiorstw przemysłowych w GOW wymaga więc dalszych rozważań o charakterze teoretycznym i kontynuacji studiów empirycznych.

\section{Literatura / References}

Acs, Z.J. (2006). How Is Entrepreneurship Good for Economic Growth? Innovations: Technology, Governance, Globalization, 1(1), 97-107.

Acs, Z., Szerb, L. (2007). Entrepreneurship, economic growth and public policy. Small Business Economics, 28(2/3), 109-122.

Audretsch, D.B., Keilbach, M.C., Lehmann, E.E. (2006), Entrepreneurship and Economic Growth. Oxford: Oxford University Press.

Berger, S., Canning, R., Dolan, M., Kurek, S., Pilz, M., Rachwał, T. (2012). Curriculum-making in pre-vocational education in the lower secondary school: A regional comparative analysis within Europe. Journal of Curriculum Studies, 44(5), 679-701, DOI: 10.1080/00220272.2012.702223.

Beugelsdijk, S. (2007). Entrepreneurial culture, regional innovativeness and economic growth. Journal of Evolutionary Economics, 17(2), p. 187-210.

Bieniok, H. (2007). Kształtowanie postaw przedsiębiorczych młodzieży w rodzinie, szkole i uczelni. W: P. Wachowiak, M. Dabrowski, B. Majewski (red.), Ksztattowanie postaw przedsiębiorczych a edukacja ekonomiczna. Warszawa: Fundacja Promocji i Akredytacji Kierunków Ekonomicznych, 224-235.

Boguś, M. (2011). Dynamika potencjału ekonomicznego korporacji ponadnarodowej Google w latach 2001-2009. Prace Komisji Geografii Przemystu Polskiego Towarzystwa Geograficznego, $17,212-224$.

Bonar, W. (2011). Funkcjonowanie korporacji Ericsson w warunkach globalnego kryzysu gospodarczego. Prace Komisji Geografii Przemystu Polskiego Towarzystwa Geograficznego, 17, 197-211.

Borowiec, M. (2008). Rola szkolnictwa wyższego w procesie kształtowania gospodarki opartej na wiedzy. Przedsiębiorczość - Edukacja, 4, 142-150.

Borowiec, M., Dorocki, S., Jenner, B. (2009). Wpływ zasobów kapitału ludzkiego na kształtowanie społeczeństwa informacyjnego i innowacyjności struktur przemysłowych. Prace Komisji Geografii Przemystu Polskiego Towarzystwa Geograficznego, 13, 95-109.

Borowiec, M., Rachwał, T. (2011). Kształtowanie postaw przedsiębiorczych na lekcjach geografii wyzwaniem edukacyjnym w procesach globalizacji. Przedsiębiorczość - Edukacja, 7, 321-332.

Brinkley, I. (2006). Defining the knowledge economy. London: The Work Foundation.

Chojnicki, Z., Czyż, T. (2006). Aspekty regionalne gospodarki opartej na wiedzy w Polsce. Poznań: Bogucki Wydawnictwo Naukowe. 
Chojnicki, Z., Czyż, T. (2007). Rola kapitału ludzkiego w kształtowaniu gospodarki opartej na wiedzy w Polsce. Przeglad Geograficzny, 79(3-4), 423-428.

Chojnicki, Z., Czyż, T. (2008). Gospodarka oparta na wiedzy w regionach metropolitalnych i aglomeracjach miejskich w Polsce. W: T. Marszał (red.), Rola polskich aglomeracji wobec wyzwań Strategii Lizbońskiej. Studia Komitetu Przestrzennego Zagospodarowania PAN, t. CXX. Warszawa: KPZK PAN, 74-95.

Cieślik, J. (2007). Kształcenie w zakresie przedsiębiorczości na poziomie akademickim. W: P. Wachowiak, M. Dabrowski, B. Majewski (red.), Kształtowanie postaw przedsiębiorczych a edukacja ekonomiczna. Warszawa: Fundacja Promocji i Akredytacji Kierunków Ekonomicznych, 71-80.

Czapliński, P. (2011). Funkcjonowanie przemysłu przetwórstwa rybnego w Polsce w okresie kryzysu gospodarczego. Prace Komisji Geografii Przemystu Polskiego Towarzystwa Geograficznego, 17, $114-128$.

Dominiak, P., Rekowski, M. (2008). The Relationship Between Entrepreneurship and Economic Growth: A Review of Recent Research Achievement. W: M.-A. Galindo, J. Huzman, D. Ribeiro (red.), Entrepreneurship and Business. A Regional Perspective. Berlin-Heidelberg: SpringerVerlag, 113-136.

Drucker, P.F. (1999). Społeczeństwo prokapitalistyczne. Warszawa: PWN.

Gabe, T., Florida, R., Mellander, C. (2013). The Creative Class and the crisis. Cambridge Journal of Regions Economy and Society, 6(1), 37-53, DOI: 10.1093/cjres/rss012.

Gaczek, W.M. (2009). Gospodarka oparta na wiedzy w regionach europejskich. Studia Komitetu Przestrzennego Zagospodarowania Kraju PAN, t. CXVIII, Warszawa.

Gierańczyk, W. (2009). Innowacyjność jako główny filar społeczeństwa informacyjnego Europy. Prace Komisji Geografii Przemystu Polskiego Towarzystwa Geograficznego, 13, 82-94.

Gierańczyk, W. (2010a). Rola własności intelektualnej w budowaniu innowacyjności krajów Unii Europejskiej. Prace Komisji Geografii Przemystu Polskiego Towarzystwa Geograficznego, 16, $76-86$.

Gierańczyk, W. (2010b). Development of high technologies as an indicator of modern industry in the EU. Bulletin of Geography. Socio-economic Series, 14, 23-36.

Gierańczyk, W., Rachwał, T. (2012). Structural changes in the industry of Poland against the background of eastern European Union states. Quaestiones Geographicae, 31(2), 83-93. DOI: 10.2478/v10117-012-0021-9.

Gurbała, M. (2010). Przemysł high-tech a poziom rozwoju społeczno-gospodarczego krajów. Prace Komisji Geografii Przemystu Polskiego Towarzystwa Geograficznego, 16, 187-200.

Innovation Union Scoreboard 2013 (2013). European Commision.

Jarczewski, W. (2007). Duch przedsiębiorczości w proinwestycyjnych działaniach władz lokalnych. Przedsiębiorczość - Edukacja, 3, 71-80.

Kilar, W. (2011). Wpływ kryzysu na funkcjonowanie korporacji Panasonic. Prace Komisji Geografii Przemystu Polskiego Towarzystwa Geograficznego, 17, 187-196.

Kitowski, J. (2009). Influence of Global Economic Crisis on Operation of Special Economic Zones in Poland. W: J. Kitowski (red.), Global Economic Crisis and Countries of Central \& Eastern Europe. Geopolitical Studies, vol. 15, Warsaw: Polish Academy of Sciences - Institute of Geography and Spatial Organization, 241-267.

Kitowski, J. (2011). Wpływ kryzysu finansowego i gospodarczego na efekty funkcjonowania specjalnych stref ekonomicznych w Polsce, W: B. Namyślak (red.), Przekształcenia regionalnych struktur funkcjonalno-przestrzennych. Współczesne kierunki przemian społeczno-ekonomicznych, 
Rozprawy Naukowe Instytutu Geografii i Rozwoju Regionalnego, 19, Wrocław: IGiRR Uniw. Wrock., 23-39.

Koźmiński, A. (2002). Jak zbudować gospodarkę opartą na wiedzy? W: G. Kołodko (red.), Rozwój polskiej gospodarki. Perspektywy i uwarunkowania. Warszawa: Wydawnictwo Wyższej Szkoły Przedsiębiorczości Zarządzania im. Leona Koźmińskiego, 155-166.

Kukliński, A. (2001). Gospodarka oparta na wiedzy. Wyzwanie dla Polski XXI wieku. Warszawa: KBN.

Kurek, S., Rachwał, T. (2010). The Role of Business Education in the Development of Entrepreneurship in the Member States of the European Union. Europa XXI, 19, 127-142.

Kurek, S., Rachwał, T. (2011). Development of entrepreneurship in ageing populations of The European Union. Procedia - Social and Behavioral Sciences, 19 (2011), 397-405.

Kurek, S., Rachwał, T., Szubert, M. (2012a). Business Competencies in Polish School Curricula: Opinions of Teachers and Social Partners. W: M. Pilz, S. Berger, R. Canning (red.), Fit for Business. Pre-Vocational Education in European Schools. Springer-Wiesbaden, 61-88. http:// dx.doi.org/10.1007/978-3-531-19028-0_4.

Kurek, S., Rachwał, T., Szubert, M. (2012b). Kształtowanie kompetencji biznesowych uczniów gimnazjum w świetle opinii nauczycieli na podstawie wyników badań prowadzonych w ramach europejskiego projektu FIFOBI. Przedsiębiorczość - Edukacja, 8, 24-36.

Lee, S.Y., Florida, R., Acs, Z. (2004). Creativity and Entrepreneurship: A Regional Analysis of New Firm Formation. Regional Studies, 38(8), 879-891.

Leydesdorff, L. (2006). The Knowledge-Based Economy: Modeled, Measured, Simulated. Boca Raton, FL: Universal Publishers.

Limański, A. (2011). Rola innowacyjności w budowaniu przewagi konkurencyjnej przedsiębiorstwa w gospodarce opartej na wiedzy. Nierówności spoleczne a wzrost gospodarczy, 23, 135-147.

Makulska, D. (2012). Kluczowe czynniki rozwoju w gospodarce opartej na wiedzy. W: J. Stacewicz (red.), Pomiędzy polityka stabilizacyjna i polityka rozwoju. Prace i Materiaty Instytutu Rozwoju Gospodarczego SGH, Warszawa: IRG SGH, 169-193.

Markowski, T. (2008). Gospodarka bazująca na wiedzy (GOW) a wyzwania wobec zagospodarowania przestrzennego - konceptualizacja problemu. W: T. Marszał (red.), Rola polskich aglomeracji wobec wyzwań Strategii Lizbońskiej. Studia Komitetu Przestrzennego Zagospodarowania Kraju $P A N$, t. CXX. Warszawa: KPZK PAN, 35-46.

Nowak, P. (2011). Funkcjonowanie sektora motoryzacyjnego w okresie kryzysu w latach 2008-2009. Prace Komisji Geografii Przemystu Polskiego Towarzystwa Geograficznego, 17, 177-186.

OECD (1996). The Knowledge-Based Economy. Paris: OECD.

OECD (2012). OECD Science, Technology and Industry Outlook. OECD Publishing, DOI: 10.1787/ sti_outlook-2012-en.

Pietrzykowski, M. (2011). Entrepreneurship in Higher Education - the case of Poland. W: M. Dabić, M. Pietrzykowski (red.), Fostering Education in Entrepreneurship. Poznań: Bogucki Wydawnictwo Naukowe, 113-128.

Powell, W.W., Snellman, K. (2004). The Knowledge Economy. Annual Review of Sociology, 30, 199220, DOI: 10.1146/annurev.soc.29.010202.100037.

Rachwał, T. (2006a). Efekty restrukturyzacji wybranych przedsiębiorstw przemysłowych Polski Południowo-Wschodniej. Prace Komisji Geografii Przemystu Polskiego Towarzystwa Geograficznego, 9, 98-115.

Rachwał, T. (2006b). Restrukturyzacja technologiczna przedsiębiorstw przemysłowych Polski Południowo-Wschodniej jako czynnik podnoszenia ich konkurencyjności na rynku międzyna- 
rodowym. Prace Komisji Geografii Przemystu Polskiego Towarzystwa Geograficznego, 8, 192 203.

Rachwał, T. (2006c). Kształtowanie postaw przedsiębiorczych w edukacji szkolnej. W: B. Muchacka (red.), Szkoła w nauce i praktyce edukacyjnej, t. II. Kraków: Oficyna Wydawnicza „Impuls”: Akademia Pedagogiczna w Krakowie, 427-434.

Rachwał, T. (2009). Changes of industry in the countries of Central and Eastern Europe under conditions of economic transformation and European integration. W: J. Kitowski (red.), Countries of Central \& Eastern Europe versus global economic crisis. Geopolitical Studies, vol. 15, Warsaw: Polish Academy of Sciences - Institute of Geography and Spatial Organization, 133-164.

Rachwał, T. (2010a). Entrepreneurship Education as a Growth Stimulus for Family Firms. W: A. Surdej, K. Wach (red.), Exploring the Dynamics of Entrepreneurship. Toruń: A. Marszałek Publishing House, 139-156.

Rachwał, T. (2010b). Struktura przestrzenna i działowa przemysłu Polski na tle Unii Europejskiej w dwudziestolecie rozpoczęcia procesów transformacji systemowej. Prace Komisji Geografii Przemystu Polskiego Towarzystwa Geograficznego, 16, 105-124.

Rachwał, T. (2011a). Wpływ kryzysu na zmiany produkcji przemysłowej w Polsce. Prace Komisji Geografii Przemystu Polskiego Towarzystwa Geograficznego, 17, 99-113.

Rachwał, T. (2011b). Transformations of the employment structure as an expression of the transformation of the Polish industry against the background of the European Union. Bulletin of Geography, Socio-economic series, vol. 15/2011, 5-25.

Rachwał, T. (2011c). Industrial restructuring in Poland and other European Union states in the era of economic globalization. Procedia - Social and Behavioral Sciences, vol. 19 (2011), 1-10.

Rachwał, T. (2012). Innowacyjność przedsiębiorstw przemysłowych jako czynnik rozwoju miast. W: Z. Makieła, A. Szromnik (red.), Miasto innowacyjne. Wiedza-Przedsiębiorczość-Marketing. Studia Komitetu Przestrzennego Zagospodarowania Kraju PAN, Tom CXLI. Warszawa: KPZK PAN, 135-152.

Repetowski, R. (2010). Konkurencyjność przedsiębiorstw w dobie globalnego kryzysu finansowego. Przedsiębiorczość - Edukacja, 6, 78-91.

Šerý, O. (2011). The impact of economic crisis on regions dominated by motor vehicles industry (the case of Vysočina Region). Prace Komisji Geografii Przemystu Polskiego Towarzystwa Geograficznego, 17, 155-163.

Skrzypek, E. (2011). Gospodarka oparta na wiedzy i jej wyznaczniki. Nierówności społeczne a wzrost gospodarczy, 23, 270-285.

Stachowiak, K. (2008). Czynniki instytucjonalne w budowaniu i funkcjonowaniu gospodarki opartej na wiedzy - przykład Finlandii. W: J.J. Parysek, T. Stryjakiewicz (red.), Region społeczno-ekonomiczny i rozwój regionalny. Poznań: Bogucki Wydawnictwo Naukowe, 121-151.

Stachowiak, K. (2009). Ewolucja przemysłu zaawansowanej technologii i sektora teleinformatycznego (ICT) w Finlandii (Evolution of the high-tech industry and the ICT sector in Finland). Prace Komisji Geografii Przemystu Polskiego Towarzystwa Geograficznego, 13, 122-132.

Stryjakiewicz, T., Kaczmarek, T., Męczyński, M., Parysek, J.J., Stachowiak, K. (2010). Polityka wspierania rozwoju sektora kreatywnego w poznańskim obszarze metropolitalnym na tle doświadczeń zagranicznych. Poznań: Bogucki Wydawnictwo Naukowe.

Stryjakiewicz, T. (1999). Adaptacja przestrzenna przemyslu $w$ Polsce $w$ warunkach transformacji. Poznań: Wydawnictwo Naukowe UAM. 
Stryjakiewicz, T. (2002). Paths of industrial transformation in Poland and the role of knowledge-based industries. W: R. Hayter, R. Le Heron (red.), Knowledge, industry and environment: Institutions and innovation in territorial perspective. Aldershot: Ashgate, 289-311.

Stryjakiewicz, T. (2008). Regiony kreatywnej wiedzy - zarys międzynarodowego projektu badawczego ACRE. W: T. Stryjakiewicz, T. Czyż (red.), O nowy kształt badań regionalnych $w$ geografii i gospodarce przestrzennej. Biuletyn Komitetu Przestrzennego Zagospodarowania Kraju PAN, 237. Warszawa: KPZK PAN, 129-145.

Stryjakiewicz, T. (2009a). Nowe spojrzenie na czynniki lokalizacji działalności gospodarczej. W: I. Jażewicz (red.), Współczesne problemy przemian strukturalnych przestrzeni geograficznej. Słupsk: Wydawnictwo Naukowe Akademii Pomorskiej.

Stryjakiewicz, T. (2009b). Lokalizacja firm i zachowania przestrzenne pracowników sektora informatycznego (na przykładzie poznańskiego obszaru metropolitalnego). Prace Komisji Geografii Przemystu Polskiego Towarzystwa Geograficznego, 13, 21-33.

Stryjakiewicz, T., Grzywińska, E., Kaczmarek, T., Męczyński, M., Parysek, J.J., Stachowiak, K. (2008). Poznan welcomes talents: Understanding the attractiveness of the metropolitan region for creative knowledge workers. ACRE report 5.8, Amsterdam: AMIDSt.

Stryjakiewicz, T., Kaczmarek, T., Męczyński, M., Parysek, J.J., Stachowiak, K. (2007). Poznan faces the future: Pathways to creative and knowledge-based regions. ACRE report 2.8, Amsterdam: AMIDSt.

Stryjakiewicz, T., Męczyński, M. (2010). Atrakcyjność poznańskiego obszaru metropolitalnego dla pracujacych w sektorze kreatywnym. Poznań: Bogucki Wydawnictwo Naukowe.

Stryjakiewicz, T., Męczyński, M., Stachowiak, K. (2009). Sektor kreatywny w poznańskiej gospodarce, Uniwersytet im. Adama Mickiewicza w Poznaniu. Poznań: Instytut Geografii SpołecznoEkonomicznej i Gospodarki Przestrzennej.

Stryjakiewicz, T., Męczyński, M., Stachowiak, K. (2008). The attractiveness of the Poznan metropolitan region for the development of the creative knowledge sector: The managers' view. ACRE report 6.8, Amsterdam: AMIDSt.

Stryjakiewicz, T., Stachowiak, K. (2010). Uwarunkowania, poziom i dynamika rozwoju sektora kreatywnego w poznańskim obszarze metropolitalnym. Poznań: Bogucki Wydawnictwo Naukowe.

Świdurska, A. (2009). Kształtowanie się przemysłu wysokiej techniki w Polsce. Prace Komisji Geografii Przemystu Polskiego Towarzystwa Geograficznego, 13, 56-67.

Świdurska, A. (2010). Efektywność rozwoju przedsiębiorstw produkcyjnych wysokiej techniki w Polsce. Prace Komisji Geografii Przemystu Polskiego Towarzystwa Geograficznego, 15, 197 208.

Szymańska, A.I (2011). Zastosowanie modeli ścieżkowych w diagnozowaniu pozycji rynkowej produktów oferowanych przez przedsiębiorstwa w warunkach kryzysu gospodarczego. Prace Komisji Geografii Przemystu Polskiego Towarzystwa Geograficznego, 17, 225-242.

Tobolska, A. (2006). Nowy model organizacji i funkcjonowania starych przedsiębiorstw przemysłowych. Prace Komisji Geografii Przemystu Polskiego Towarzystwa Geograficznego, 9, 81-97.

Tobolska, A. (2011). Czynniki lokalizacji fabryk wybranych korporacji międzynarodowych w Polsce. W: M. Wdowicka, L. Mierzejewska (red.), Problemy rozwoju lokalnego i regionalnego na poczatku XXI wieku. Biuletyn Instytutu Geografii Społeczno-Ekonomicznej i Gospodarki Przestrzennej UAM, Seria Rozwój Regionalny i Polityka Regionalna, 15, 55-66.

Valliere, D., Peterson, R. (2009). Entrepreneurship and economic growth: Evidence from emerging and developed countries. Entrepreneurship and Regional Development, 21(5-6), 459-480. 
Wach, K. (2007). Kształtowanie postaw przedsiębiorczych w programach nauczania. Stan obecny i proponowane kierunki zmian. W: P. Wachowiak, M. Dabrowski, B. Majewski (red.), Ksztattowanie postaw przedsiębiorczych a edukacja ekonomiczna. Fundacja Promocji i Akredytacji Kierunków Ekonomicznych, Warszawa, 120-127.

Wennekers, A.R.M., Thurik, A.R. (1999). Linking entrepreneurship and economic growth. Small Business Economics, 13(1), 27-55

Wójtowicz, M. (2011). Wpływ światowego kryzysu gospodarczego na brazylijski i meksykański przemysł samochodowy. Prace Komisji Geografii Przemystu Polskiego Towarzystwa Geograficznego, 17, 129-143.

Zavloschi-Dunareanu, L. (2013). The Knowledge Management in the Modern Industrial Company. Metalurgia International, 18(1), 231-234.

Zioło, Z. (1996). Model funkcjonowania przestrzeni geograficznej i jego znaczenie dla gospodarki przestrzennej. W: U. Wich (red.), Gospodarka, przestrzeń, środowisko. Lublin: Wyd. UMCS, 239-250.

Zioło, Z. (1999). Model funkcjonowania przestrzeni geograficznej jako próba integracji badań geograficznych. W: A. Lisowski (red). Geografia na przełomie wieków - jedność w różnorodności. Warszawa: Wydział Geografii i Studiów Regionalnych Uniwersytetu Warszawskiego, 122-131.

Zioło, Z. (2003). Kształtowanie się przedsiębiorstw przemysłowych w procesie globalizacji. Prace Komisji Geografii Przemystu Polskiego Towarzystwa Geograficznego, 6, 9-19.

Zioło, Z. (2006). Rola przedsiębiorczości w podnoszeniu konkurencyjności społeczeństwa i gospodarki. Przedsiębiorczość - Edukacja, 2, 10-17.

Zioło, Z. (2007). Rola przedsiębiorczości w aktywizacji gospodarczej-zarys modelu. Przedsiębiorczość - Edukacja, 3, 10-17.

Zioło, Z. (2008). Ekonomiczne i społeczne uwarunkowania rozwoju gospodarki opartej na wiedzy. Przedsiębiorczość - Edukacja, 4, 12-23.

Zioło, Z. (2009a). Rola przedsiębiorczości w kształtowaniu społeczeństwa informacyjnego. Przedsiębiorczość - Edukacja, 5, 10-18.

Zioło, Z. (2009b). Rola przemysłu w procesie kształtowania społeczeństwa informacyjnego. Prace Komisji Geografii Przemystu Polskiego Towarzystwa Geograficznego, 13, 11-20.

Zioło, Z. (2009c). Model badań procesu transformacji elementów w przestrzeni geograficznej. W: I. Jażewicz (red.), Wspótczesne problemy przemian strukturalnych przestrzeni geograficznej (książka dedykowana Profesorowi Eugeniuszowi Rydzowi w 70. Rocznicę urodzin). Słupsk: Akademia Pomorska, 103-117.

Zioło, Z. (2011). Wpływ światowego kryzysu na tempo wzrostu gospodarki i światowych korporacji. Prace Komisji Geografii Przemystu Polskiego Towarzystwa Geograficznego, 17, 9-32.

Zioło, Z. (2012a). Miejsce innowacyjności w kształtowaniu procesów rozwoju gospodarczego układów przestrzennych. Prace Komisji Geografii Przemystu Polskiego Towarzystwa Geograficznego, 20, 9-32.

Zioło, Z. (2012b). Miejsce przedsiębiorczości w edukacji. Przedsiębiorczość - Edukacja, 8, 10-23.

Zioło, Z., Rachwał T. (2012). Entrepreneurship in geographical research, W: P. Churski (red.), Contemporary Issues in Polish Geography. Poznań: Bogucki Wydawnictwo Naukowe, 135-155. 
Tomasz Rachwal, dr, Uniwersytet Pedagogiczny w Krakowie, Instytut Geografii, Zakład Przedsiębiorczości i Gospodarki Przestrzennej.

Geograf ekonomiczny. Członek Krajowej Rady Przedsiębiorczości. Pełni m.in. funkcję Kierownika Zakładu Przedsiębiorczości i Gospodarki Przestrzennej Instytutu Geografii Uniwersytetu Pedagogicznego w Krakowie, Sekretarza Naukowego Komisji Geografii Przemysłu Polskiego Towarzystwa Geograficznego, Zastępcy Redaktora Naczelnego czasopism Prace Komisji Geografii Przemystu Polskiego Towarzystwa Geograficznego, Przedsiębiorczość - Edukacja oraz Annales Universitatis Paedagogicae Cracoviensis Studia Geographica. Jego zainteresowania badawcze skupiają się przede wszystkim na problematyce przemian struktur przestrzennych przemysłu, funkcjonowania różnych branż działalności gospodarczej, restrukturyzacji przedsiębiorstw oraz roli przedsiębiorczości w rozwoju układów przestrzennych a także edukacji w zakresie przedsiębiorczości.

Tomasz Rachwal, Ph.D., Pedagogical University of Cracow, Institute of Geography, Department of Entrepreneurship and Spatial Management.

Economic geographer. Member of the National Council for Entrepreneurship. He is the Head of the Department of Entrepreneurship and Spatial Management - Institute of Geography, Pedagogical University of Cracow, Scientific Secretary of the Industrial Geography Committee of the Polish Geographical Society, Deputy Editor in Chief of the following journals: Studies of the Industrial Geography Commission of the Polish Geographical Society, Entrepreneurship - Education and Annales Universitatis Paedagogicae Cracoviensis Studia Geographica, among others. His research interests focus primarily on the issue of change of the spatial structures of industry, functioning of various branches of industrial activity, corporate restructuring and the role of entrepreneurship in the development of spatial systems and entrepreneurship education.

adres/address: Uniwersytet Pedagogiczny w Krakowie

Instytut Geografii, Zakład Przedsiębiorczości i Gospodarki Przestrzennej

ul. Podchorążych 2, 30-084 Kraków, Polska

e-mail: T.Rachwal@up.krakow.pl 